\title{
EVALUATION OF THE DEGREE OF DEGRADATION USING THE IMPACT-ECHO METHOD IN CIVIL ENGINEERING
}

\author{
OCENA STOPNJE DEGRADACIJE V GRADBENIŠTVU Z \\ UPORABO METODE ODMEVA ZVOČNIH VALOV
}

\author{
Daniela Štefková, Kristýna Timčaková, Libor Topolář, Petr Cikrle \\ Brno University of Technology, Faculty of Civil Engineering, Veveří331/95, 60200 Brno, Czech Republic \\ stefkova.d@fce.vutbr.cz \\ Prejem rokopisa - received: 2015-06-30; sprejem za objavo - accepted for publication: 2015-12-15
}

doi:10.17222/mit.2015.150

\begin{abstract}
Non-destructive methods such as Impact-echo method are based on the acoustic properties of the material that are dependent on its condition. It allows the studied progress development of micro-defects in the structure of the material and is thus suitable for monitoring the building structure's condition. This acoustic method allows us to identify and locate defects and is thus suitable for monitoring the building structure's condition. The application of this method is widespread; it can be used in mechanical engineering, power engineering and in many industries as well as in the construction industry. Impact-echo uses a short-time mechanical impulse (a hammer blow) that is applied to a surface of the test sample and is detected by means of piezoelectric sensors placed on the surface of the sample. The impulse is reflected by the surface but also by micro-cracks and defects of the specimen that are under investigation. From thus obtained signal the frequency spectrum is determined and is found to be the dominant resonance frequency using fast Fourier transformations. The dominant frequencies give an account of the condition of the structure or determine the location of flaws, at which the waves are rebounded. The signal is digitized by means of a data processing system to be transferred into a computer memory. A piezoelectric MIDI sensor takes the signal response and it is brought to the input of an oscilloscope TiePie engineering Handyscope HS3 two-channel with 16-bit resolution. This paper reports the results of measurements by the Impact-echo method on three applications in civil engineering. The results are obtained in the laboratory during the hardening process in quasi-brittle materials such as alkali-activated slag mortars, the degradation of concrete samples by corrosion caused by the action of chlorides and the degradation of composite materials based on cement by high temperature.
\end{abstract}

Keywords: predominant frequency, high temperature, impact, mortar, specimens

Neporušna metoda, kot je npr. odmev zvočnih valov, temelji na akustičnih lastnostih materiala, ki so odvisne od stanja materiala. Metoda omogoča študij napredovanja mikronapak v strukturi materiala in je zato primerna za pregled stanja gradbene strukture. Ta akustična metoda omogoča odkrivanje in določanje položaja napake in je zato primerna za pregled stanja zgradbe. Metoda ima široko uporabnost, saj se lahko uporablja v strojništvu, energetiki ter v mnogih drugih industrijah kot tudi v gradbeništvu. Metoda odmeva zvočnih valov uporablja kratke mehanske udarce (udarec s kladivom) po površini preizkušanega vzorca, odmeve pa se določi s piezoelektričnim senzorjem, ki je tudi nameščen na površini. Impulz odseva površino in tudi mikrorazpoke in napake $\mathrm{v}$ vzorcu, ki se ga preiskuje. Iz tako dobljenega signala, se določi spekter frekvenc in s pomočjo hitre Fourierjeve transformacije se poišče prevladujoča resonančna frekvenca. Prevladujoče frekvence pokažejo stanje zgradbe ali pa določijo lokalne pomanjkljivosti, na katerih valovi poskočijo. Signal se digitalizira s sistemom obdelave podatkov, da se ga lahko prenese v spomin računalnika. Piezoelektrični sensor MIDI prevzame odbit signal, ki se ga usmeri na vhod dvokanalnega osciloskopa TiePie Engineering Handyscope HS3, z ločljivostjo 16 bitov. Članek predstavlja rezultate meritev z metodo odmeva zvočnih valov na treh primerih v gradbeništvu. Rezultati so dobljeni v laboratoriju med procesom utrjevanja v kvazi krhkem materialu, kot je z alkalijami aktivirana žlindra v maltah, degradacijo betonskih vzorcev zaradi korozije, povzročeno $\mathrm{s}$ kloridi in visoko temperaturno degradacijo kompozitnega materiala na osnovi betona

Ključne besede: prevladujoča frekvenca, visoka temperatura, udarec, malta, vzorci

\section{INTRODUCTION}

In civil engineering, efficient non-destructive quality control plays an important role in the optimization of resources for manufacturing, maintenance and safety. The impact-echo method is a useful non-destructive technique for flaw detection in concrete. It is based on monitoring the surface motion, resulting from a shorttime mechanical impulse. This method overcomes many of the barriers associated with flaw detection in concrete that occur during ultrasonic methods. One of the key features of this method is the transformation of the recorded time-domain waveform of the surface motion into the frequency domain. The impact gives rise to modes of vibration and the frequency of these modes is related to the geometry of the tested object and the presence of flaws. ${ }^{1}$

A short-time mechanical impulse, generated by tapping a hammer against the surface of a concrete structure (Figure 1), produces low-frequency stress waves that propagate into the structure..$^{2,3}$ Thus generated waves propagate through the specimen structure and reflect from the defects located in the volume of the specimen or in the surface. Surface displacements caused by the reflected waves are recorded by a transducer located adjacent to the impact. ${ }^{4}$ The signal is digitized by an analogue/digital data system and transmitted to a computer memory. This signal describes the transient local vibrations, which are caused by the mechanical wave 


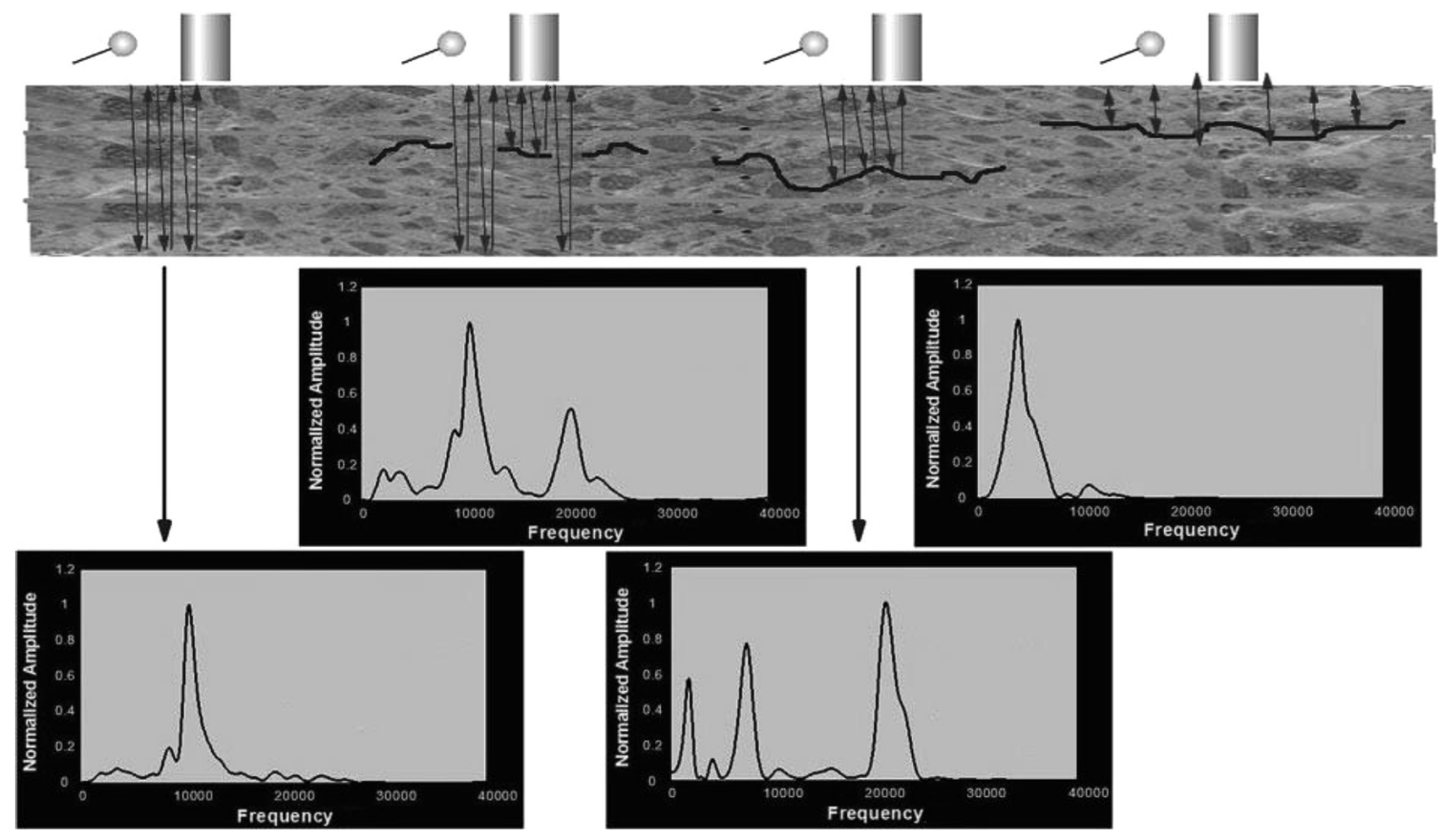

Figure 1: Principle of the Impact echo method

Slika 1: Princip metode odmeva zvočnih valov

multiple reflections inside the structure. The dominant frequencies of these vibrations give an account of the condition of the structure that the waves pass through. 5,6

The signal analysis from the impact-echo method is most frequently performed by using frequency spectra obtained from the fast Fourier transform. Fourier analysis converts time to frequency and vice versa. A fast Fourier transform (FFT) is an algorithm to compute the discrete Fourier transform (DFT) and it is inverse. The results of fast Fourier transforms are widely used for many applications in engineering, science, and mathematics. Equation (1) is the expression of the Fourier transform for a continuous function: ${ }^{7}$

$$
\begin{gathered}
x(t)=\frac{a_{0}}{2}+\sum_{n=1}^{\infty}\left[a_{n} \cdot \cos \left(\frac{2 \pi n t}{T}\right)+b_{n} \cdot \sin \left(\frac{2 \pi n t}{T}\right)\right] \\
a_{n}=\frac{2}{T} \cdot \int_{0}^{T} x(t) \cos \left(\frac{2 \pi n t}{T}\right) \mathrm{d} t \\
b_{n}=\frac{2}{T} \cdot \int_{0}^{T} x(t) \sin \left(\frac{2 \pi n t}{T}\right) \mathrm{d} t \\
\frac{2 \pi}{T}=\omega
\end{gathered}
$$

where $a_{\mathrm{n}}$ and $b_{\mathrm{n}}$ can be calculated from function $x(t)$ using the following relations.

\section{EXPERIMENTAL PART}

For the impact-echo method a short-time mechanical impulse (a hammer blow) was applied to the surface of the specimen during the test and was detected by means of a piezoelectric sensor (Figure 2). The impulse reflects from the surface but also from micro-cracks and defects present in the specimen that are under investigation. The frequency analysis can be carried out from the response signal by means of a fast Fourier transform and thus dominant resonant frequencies are found. An MIDI piezoelectric sensor was used to pick up the response and the respective impulses were directed into the input of an oscilloscope TiePie engineering Handyscope HS3 twochannel with a 16-bit resolution.

\subsection{Material for the hardening process of alkali-acti- vated slag mortars}

The mixture consisted of $450 \mathrm{~g}$ of fine-grained granulated blast furnace slag Štramberk 380 (specific surface area $380 \mathrm{~m}^{2} \mathrm{~kg}^{-1}$ ), $180 \mathrm{~g}$ of sodium silicate (water glass) with a modulus of $1.6,1350 \mathrm{~g}$ of silica sand (maximum grain size of $2.5 \mathrm{~mm}$ ) and $95 \mathrm{~mL}$ of water. The amount of admixtures was $0.1 \%$ of mass fractions with respect to the slag. CNTs were added in the form of a well-dispersed aqueous dispersion containing $1 \%$ of mass fractions of multi-walled carbon nanotubes

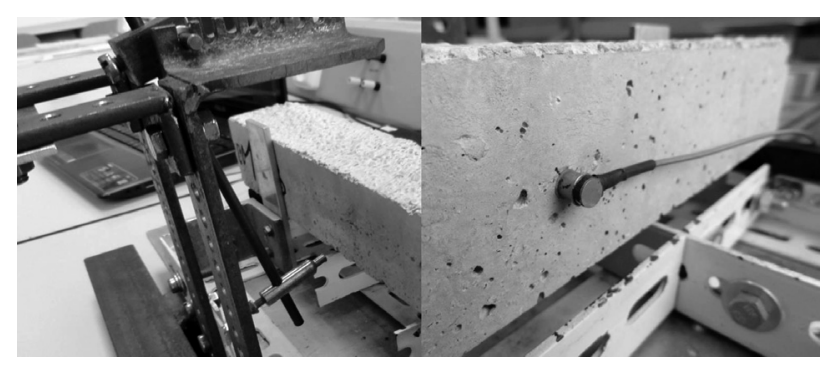

Figure 2: Images of measurement with the Impact-Echo method Slika 2: Posnetka merjenja z metodo odmeva zvočnih valov 
(Graphistrengths CW 2-45). Since CNTs are commonly not water-soluble, the dispersion also contained carboxymethyl cellulose $(68 \mathrm{~g} / \mathrm{L})$ as a dispersing agent. ${ }^{8}$ The slurry was poured into steel moulds $40 \mathrm{~mm} \times 40 \mathrm{~mm} \times$ $160 \mathrm{~mm}$ to set. The samples were demoulded after $24 \mathrm{~h}$ and one set was tested (marked $0 \mathrm{~d}$ ) and the second set was immersed in water for another $28 \mathrm{~d}$ before testing (marked $28 \mathrm{~d}$ ).

\subsection{Material for the degradation of concrete samples by corrosion caused by the action of chlorides}

The mixture for the production of concrete samples was composed of cement CEM II/B - S 32.5 and 1350 $\mathrm{kg}$ of sand with a fraction of aggregate $0-4 \mathrm{~mm}$ and $225 \mathrm{~L}$ of water. The high water ratio resulted in easier penetration of the degradation agents into the concrete structure. These samples of dimensions $50 \mathrm{~mm} \times 50 \mathrm{~mm}$ $\times 330 \mathrm{~mm}$ were reinforced with one standard reinforcing bar of diameter $10 \mathrm{~mm}$ and a length of $400 \mathrm{~mm}$ passing through the centre of the beam.

The samples were demoulded after $24 \mathrm{~h}$ and placed in the water for $27 \mathrm{~d}$, then the dried samples with natural humidity were exposed to accelerated degradation by chlorides. The samples were immersed into a $5 \%$ water solution of $\mathrm{NaCl}$ for $16 \mathrm{~h}$ and then subsequently placed into a drying oven with an air temperature of $40{ }^{\circ} \mathrm{C}$ for $8 \mathrm{~h}$.

\subsection{Specimens intended to be subjected in the heating process}

Mortars of dimensions $40 \mathrm{~mm} \times 40 \mathrm{~mm} \times 160 \mathrm{~mm}$ were produced using a type CEM I $42.5 \mathrm{R}$ Portland cement (Českomoravský Cement-Heidelberg Cement Group) and a water-to-cement ratio $(w / c=0.46)$ and quartz sand from Filtrační písky, s.r.o. for the preparation of the test mortar mixture in a ratio of 1 to 3 , in compliance with the ČSN 721200 standard. The specimens were left in the moulds for $24 \mathrm{~h}$, then cured in water for $27 \mathrm{~d}$ and finally air-cured for $31 \mathrm{~d}$ at laboratory temperature $\left(25 \pm 2{ }^{\circ} \mathrm{C}\right)$ and a relative humidity of $53 \pm 5 \%$.

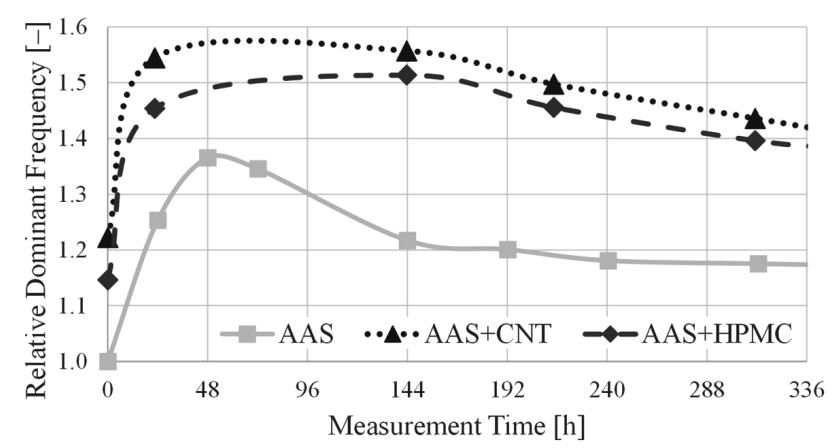

Figure 3: Change of relative dominant frequencies over time - without curing

Slika 3: Spreminjanje relativne prevladujoče frekvence s časom - brez utrjevanja
After initial curing, the specimens were dried at a temperature of $60{ }^{\circ} \mathrm{C}$ for two d. Subsequently, the specimens were subjected to gradual heating in a furnace at $200{ }^{\circ} \mathrm{C}, 400{ }^{\circ} \mathrm{C}, 600{ }^{\circ} \mathrm{C}, 800{ }^{\circ} \mathrm{C}, 1000{ }^{\circ} \mathrm{C}$ and $1200{ }^{\circ} \mathrm{C}$. The temperature increase rate was $5^{\circ} \mathrm{C} / \mathrm{min}$. A dwell of $60 \mathrm{~min}$ at each temperature was provided, in order to find out the effect of temperature on the specimens. After heat treatment, the specimens were left to cool down under laboratory conditions.

\section{RESULTS AND DISCUSION \\ 3.1 Material for the hardening process of alkali- activated slag mortars}

The experiment was employed to determine the microstructural changes during the hardening process of the alkali-activated slag composite with different admixtures. Changes in the density of the material due to the process of hardening as well as the creation of microcracks due to the time of curing are reflected in the shift of dominant frequencies. Figure 3 shows the shift of the resonance frequency during $14 \mathrm{~d}$ after demoulding without curing. The frequency of the reference specimen (AAS) increased by about $37 \%$ during the first $48 \mathrm{~h}$ from the start of the measurement and then decreased to a steady value of around $18 \%$ from the initial value. The dominant frequency of the AAS+CNT (AAS+HPMC) specimen started $21 \%(15 \%)$ above the initial dominant frequency of the reference specimen (AAS). The dominant frequency of the AAS+CNT (AAS+HPMC) increased by about $35 \%$ (30\%) from the initial value during the first $24 \mathrm{~h}$ and then decreased to a steady value of around $23 \%(25 \%)$ from the initial value. The process of hardening and the formation of a hard and dense structure caused an initial increase of the dominant frequencies. At a later time, the frequencies are again slightly shifted towards lower values. This phenomenon is probably associated with the drying process, which is followed by the shrinkage of the AAS matrix and the formation of micro-cracks. Figure 4 shows the shift of the resonance frequency during $14 \mathrm{~d}$ after $28 \mathrm{~d}$ of curing. The dominant frequency decreased for all the measure-

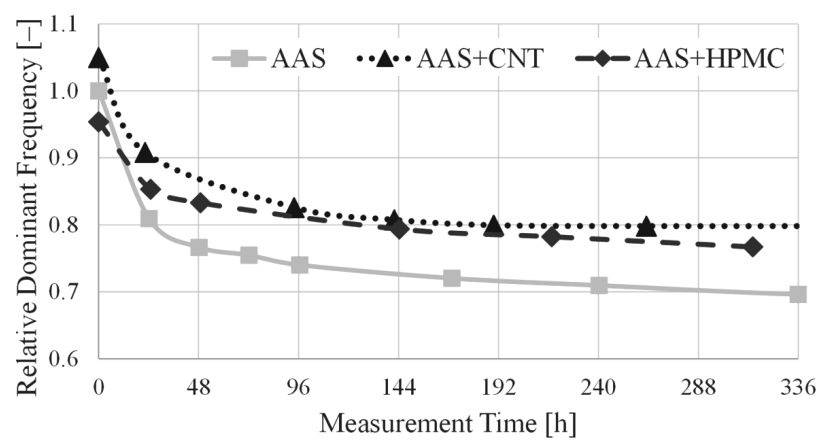

Figure 4: Change of relative dominant frequencies over time - after $28 \mathrm{~d}$ of curing

Slika 4: Spreminjanje relativne prevladujoče frekvence s časom - po 28 dneh utrjevanja 
ment times to a stable value. For the AAS specimen there was a stable value of about $70 \%$ of the initial value. For AAS+CNT (AAS+HPMC) there was a decline of about $25 \%(20 \%)$ from the initial value. This decline is mainly associated with the drying process, which is followed by shrinkage of the AAS matrix and probably the formation of micro-cracks. Whereas that dominant frequency obtained for specimens with admixtures was higher than for the reference sample, then both admixtures have a positive effect on the formation of a structure of alkali-activated slag composite. Both cellulose derivatives that were added to mixture are able to retain water. These admixtures prevent the material from rapidly drying and the subsequent formation of the micro-cracks caused by drying shrinkage, which generally occurs during hardening of the samples. Carbon nanotubes employed in one set of samples can act as a micro-reinforcement, it participates on the improvement of the mechanical properties.

\subsection{Material for degradation of concrete samples by corrosion caused by the action of chlorides}

Measuring the effect of corrosion on reinforced concrete samples was carried out on two sets of samples. The first set of samples was a reference and the second set of samples was subjected to corrosion by using accelerated degradation by chlorides in an aqueous $\mathrm{NaCl}$ solution. The measurements were always carried out after 20 cycles of alternating immersion in an aqueous $\mathrm{NaCl}$ solution and drying in an oven. In Figure 5 we can see the relative change of the dominant frequencies, when the piezoelectric sensor was placed at one end of the concrete beam and hit by a steel hammer at the opposite end of the concrete beam in the longitudinal direction. Figure 6 shows the relative change of dominant frequencies for the same samples, but measurements were carried out so that the sensor was placed at one end uncovered reinforcement and the hit was made at the opposite end of reinforcement in the longitudinal direction. The signal passing through the degraded sample changes the frequency by reflections on the inhomoge-

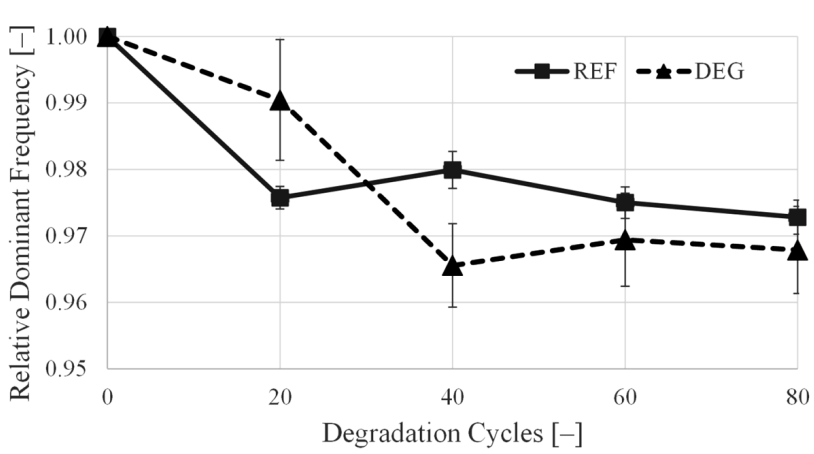

Figure 5: Change of the relative dominant frequencies during degradation cycles (impact and sensor on material)

Slika 5: Spreminjanje relativne prevladujoče frekvence med cikli propadanja (udarec in senzor na materialu)

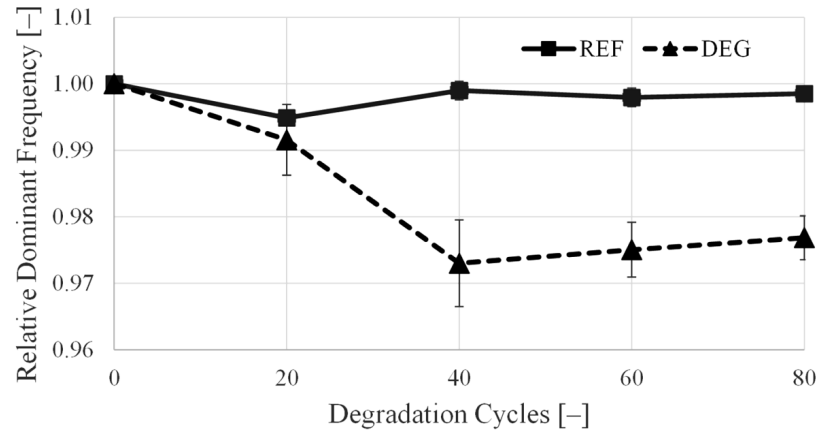

Figure 6: Change of relative dominant frequencies during degradation cycles (impact and sensor on reinforcement)

Slika 6: Spreminjanje relativne prevladujoče frekvence med cikli propadanja (udarec in senzor na betonu)

neities, which is an indicator of changes in the structure. The results are referenced to a relative value and are displayed in the form of an arithmetic average (obtained from three independent measurements for reference samples and from six measurements for degraded samples) and standard deviations as error bars. In the first case, for measurements of the samples on concrete, the dominant frequencies of reference samples was a decrease of $2.4 \%$, which can be explained by a lack of water for the hydration of the concrete, therefore this decrease is not as significant for immersed samples, only about $1.0 \%$. In the case of measurements on reinforcement the phenomenon associated with hydration is not apparent, it is only within the measurement error. Between 20 and 40 cycles of degradation occurred in the samples to the formation of observable cracks due to expansion of the corrosion products. This phenomenon is reflected in a significant decrease of the monitored frequencies. For measurements on concrete the decrease was $2.5 \%$ and for a measurement on reinforcement it was $1.9 \%$. Other frequency changes are no longer significant. The results obtained correspond to the processes that occur during the degradation of the reinforced concrete and reveal damage reinforced concrete.

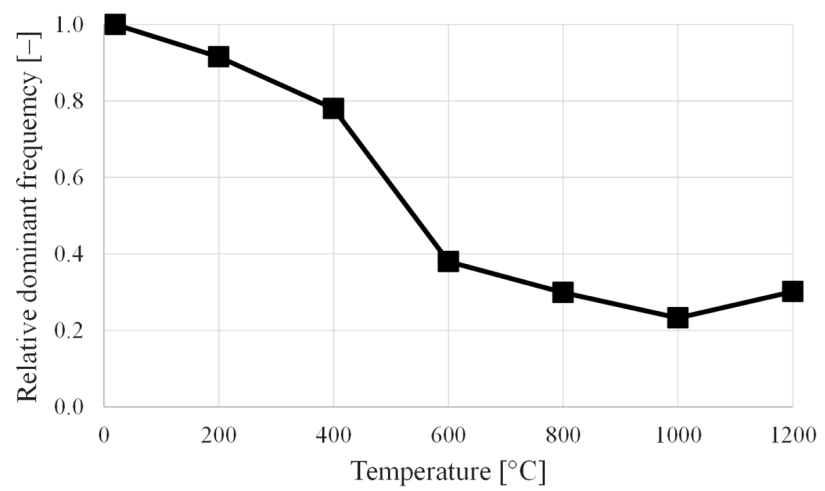

Figure 7: Shift of dominant frequency induced by degradation at elevated temperatures (Arrangement U0-S0)

Slika 7: Premik prevladujoče frekvence povzročen z razpadanjem pri povišanih temperaturah (Postavitev U0-S0) 


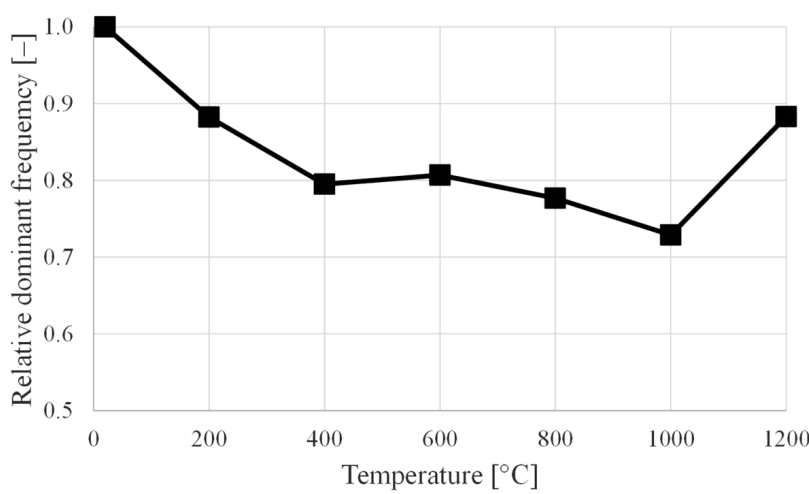

Figure 8: Shift of dominant frequency induced by degradation at elevated temperatures (Arrangement U1-S1)

Slika 8: Premik prevladujoče frekvence povzročen z razpadanjem pri povišanih temperaturah (Postavitev U1-S1)

\subsection{Specimens intended to be subjected in a heating process}

The mortar specimens of the compositions were exposed to the temperatures of 200, 400, 600, 800, 1000 and $1200{ }^{\circ} \mathrm{C}$. The test results of impact-echo are presented below. Figure 7 presents the change of dominant frequency versus temperature at which the specimens of mortar compositions were subjected (arrangement U0-S0; longitudinal waves). For this measurement, the sensor was placed at the specimen's end at its centre line direction, while the specimen was hit at the opposite end at the centre line direction - arrangement U0-S0. Longitudinal waves, which propagate within the sample at a speed of about $5100 \mathrm{~m} / \mathrm{s}$, can affect the mortar element oscillations. The exposure at elevated temperatures causes a decrease of the dominant frequency, leading to the conclusion that the material's elastic modulus for each composition also decreases $\left(E=4 \pi \cdot(f \cdot L)^{2}\right)$. Predominant frequencies are shifted towards to the lower frequency range in the course of the degradation. The change is more rapid in the temperature range $400-600{ }^{\circ} \mathrm{C}$, where are intense impurities changed. It is clear that the predominant frequencies shifted down towards the lower frequency region. For the specimen that underwent a thermal stress at a temperature of $1200{ }^{\circ} \mathrm{C}$ it is clear that the predominant frequencies shifted upwards towards the higher-frequency region. It is evident that a structural change, accompanied by the creation of new crystal phases, takes place in the specimen at temperatures of about $1200{ }^{\circ} \mathrm{C}$. Figure 8 shows the change of dominant frequency versus temperature when the arrangement was the U1-S1 one. In this case, transverse waves (gradual waves) are predominantly spread throughout the specimens. The difference between the U0-S0 and U1-S1 arrangements is that in the latter the measurement took place with the sensor being placed at the mid-point and perpendicular to the specimen. The specimen was hit at the mid-point opposite to the sensor. The dependence of frequency on temperature was similar to that observed when the U0-S0 arrangement was used, however the frequency values were lower in the case of the U1-S1 arrangement. This is similar to the case of the U0-S0 arrangement (Figure 7). The comparison of Figures 7 and 8 indicates that the frequency change is slower when the arrangement U1-S1 is applied. In general, acoustic methods illustrated the physical changes in the structure of all the tested materials. A reduction of the predominant frequency values was observed. Moreover, it was also observed in every case of elevated temperature. The heating up to $110{ }^{\circ} \mathrm{C}$ resulted in a loss of capillary water and a reduction of the cohesive forces (weakening of bonds) due to moisture evaporation. At about $170{ }^{\circ} \mathrm{C}$ decomposition of gypsum occurred, resulting in expansive spalling. Between 250 and $300{ }^{\circ} \mathrm{C}$ the hydrated cement phases were decomposed, while above $300{ }^{\circ} \mathrm{C}$ it resulted in $\mathrm{Ca}(\mathrm{OH})_{2}$ decomposition. Further temperature increases up to $300{ }^{\circ} \mathrm{C}$ or $400{ }^{\circ} \mathrm{C}$ intensified the cement paste's thermal decomposition and degradation. All the mentioned changes resulted in the embrittlement and hardening of the tested materials. Thus, the observed reduction of frequency values was assumed to be due to the formation of micro-cracks.

\section{CONCLUSIONS}

The paper deals with the results of measurements using the Impact-echo method on three applications in civil engineering. The aim of this paper was to study the application of the impact-echo method for the detection of flaws in composite materials during different stress situations (setting and hardening in air, degradation by corrosion caused by chlorides and exposing to elevated temperature). It is known that the impact response signal of a specimen is composed of frequencies corresponding to the modes of vibration of the specimen. A shift of the dominant frequency to a lower value is a key indication of the presence of the flaw. From the results obtained in the framework of our research group and the results demonstrated in this paper it can be summarized that the frequency inspection carried out by means of the Impact-echo method makes a convenient tool to assess the quality and lifetime of these composite materials when exposed to stress situations.

\section{Acknowledgement}

This paper has been worked out under the project GAČR No.16-02261S supported by Czech Science Foundation and the project No. LO1408 "AdMaS UP Advanced Materials, Structures and Technologies", supported by Ministry of Education, Youth and Sports under the "National Sustainability Programme I" and under the project No.J-16-3254 supported by Faculty of Civil Engineering of BUT. 


\section{D. ŠTEFKOVÁ et al.: EVALUATION OF THE DEGREE OF DEGRADATION USING THE IMPACT-ECHO METHOD ...}

\section{REFERENCES}

${ }^{1}$ N. J. Carino, Structures Congress and Exposition 2001, Proceedings, American Society of Civil Engineers, Washington, DC, 2001, 1-18

${ }^{2}$ B. Kucharczyková, P. Misák, T. Vymazal, Determination and evaluation of the air permeability coefficient using Torrent Permeability Tester, Russian Journal of Nondestructive Testing, 46 (2010) 3, 226-233, doi:10.1134/ S1061830910030113

${ }^{3}$ T. Vymazal, N. Žižková, P. Misák, Prediction of the risks of design and development of new building materials by fuzzy inference systems, Ceramics-Silikáty, 53 (2009) 3, 216-445

${ }^{4}$ I. Plšková, M. Matysík, Z. Chobola, Evaluation of ceramic tiles frost resistance using Impact Echo Method, In 10th International Conference of the Slovenian Society for Non-Destructive Testing: Application of Contemporary Non-Destructive Testing in Engineering, Ljubljana, 2009, 333-340
${ }^{5}$ M. Matysík, M. Kořenská, I. Plšková, NDT of freeze-thaw damaged concrete specimens by nonlinear acoustic spectroscopy method, In 10th International Conference of the Slovenian Society for NonDestructive Testing: Application of Contemporary Non-Destructive Testing in Engineering, Ljubljana, 2009, 317-323

${ }^{6} \mathrm{M}$. T. Liang, P. J. Su, Detection of the corrosion damage of rebar in concrete using impact-echo method, Cement \& Concrete Research, 31 (2001), 1427-1436, doi:10.1016/S0008-8846(01)00569-5

${ }^{7}$ E. Birgham, Fast Fourier Transform and Its Applications, 1st ed., Prentice Hall, New Jersey 1988, 448

${ }^{8}$ L. Topolár, H. Šimonová, P. Rovnaník, P. Schmid, The Effect of the Carbon Nanotubes on the Mechanical Fracture Properties of Alkali Activated Slag Mortars, In Dynamic of Civil Engineering and Transport Structures and Wind Engineering, Applied Mechanics and Materials, Donovaly, 2014, 243-246, doi:10.4028/www.scientific. net/AMM.617.243 